This item was submitted to Loughborough's Research Repository by the author.

Items in Figshare are protected by copyright, with all rights reserved, unless otherwise indicated.

\title{
European cities in globalization: a comparative analysis based on the location strategies of advanced producer services
}

PLEASE CITE THE PUBLISHED VERSION

http://dx.doi.org/10.1007/978-3-642-35801-2_12

PUBLISHER

(c) Springer

VERSION

AM (Accepted Manuscript)

LICENCE

CC BY-NC-ND 4.0

\section{REPOSITORY RECORD}

Taylor, Peter J., Michael Hoyler, and Simon Sanchez-Moral. 2019. "European Cities in Globalization: A Comparative Analysis Based on the Location Strategies of Advanced Producer Services". figshare. https://hdl.handle.net/2134/12971. 
This item was submitted to Loughborough's Institutional Repository (https://dspace.lboro.ac.uk/) by the author and is made available under the following Creative Commons Licence conditions.

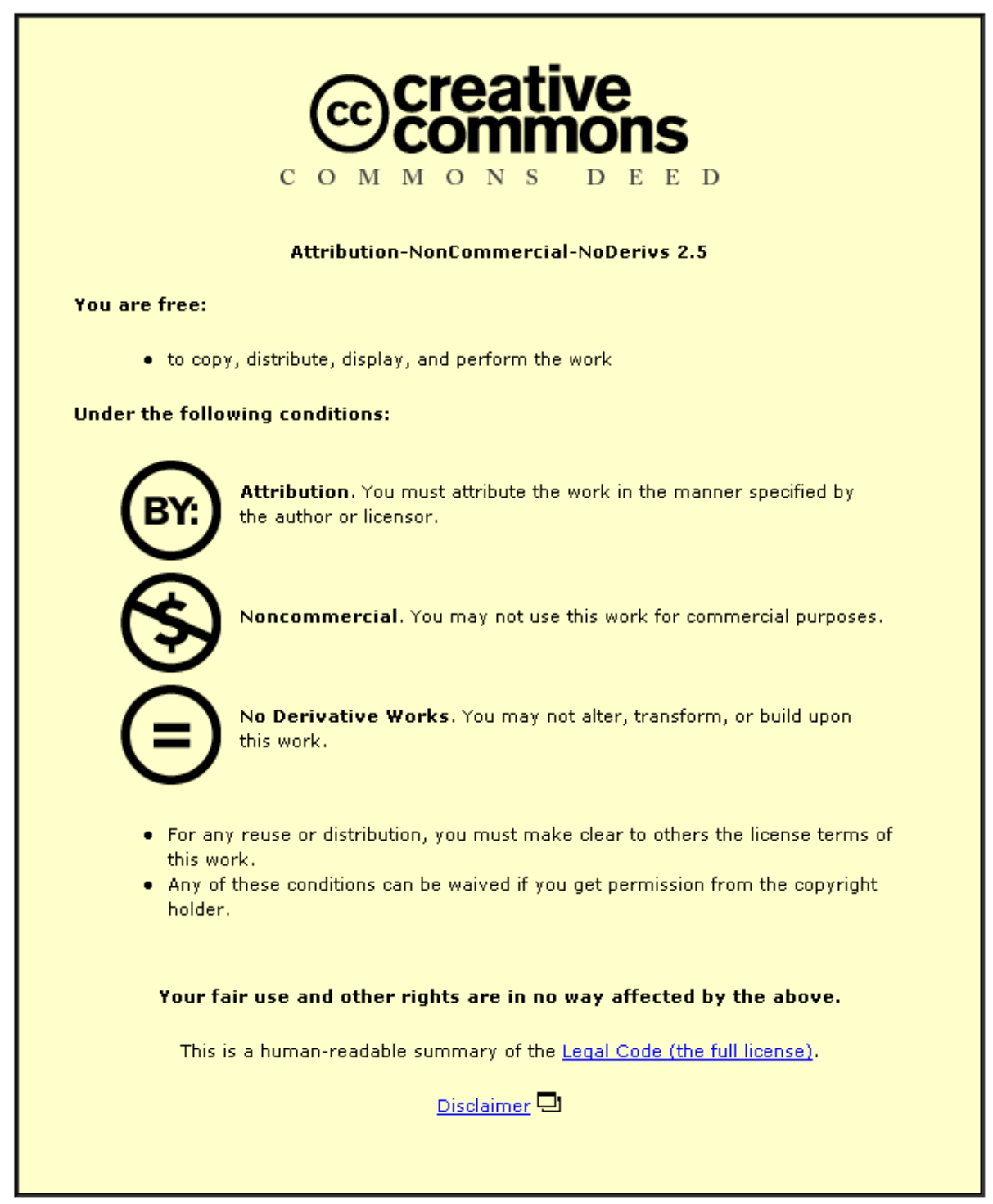

For the full text of this licence, please go to: http://creativecommons.org/licenses/by-nc-nd/2.5/ 


\title{
European Cities in Globalization: \\ A Comparative Analysis Based on the Location Strategies of Advanced Producer Services
}

\author{
Peter J. Taylor ${ }^{1}$, Michael Hoyler ${ }^{2}$, and Simón Sánchez-Moral ${ }^{3}$ \\ ${ }^{1}$ Human Geography, Northumbria University, Newcastle upon Tyne, UK \\ 2Department of Geography, Loughborough University, Loughborough, UK \\ ${ }^{3}$ Department of Regional Geographical Analysis, Complutense University, \\ Madrid, Spain
}

\section{Introduction: Comparisons Between Countries and Relations Between Cities}

Today there is a key question that lurks behind any consideration of Europe and its cities: is this foundation core zone of the modern world-system showing symptoms of dropping out of the contemporary core zone? It certainly appears that in the period of crises since 2008, Europe has been falling behind other major world-regions. Dubbed the "austerity region" of the world, such an interpretation sees Europe as the first part of the worldeconomy core to be subject to what are effectively structural adjustment programmes, largely self-imposed but still resulting in a process of peripheralization. Although uneven in impact, this is clearly a result of Europe's states failing to adequately manage and regulate the economic activities within their territories. However it is far too soon to say whether such a monumental global economic shift is happening but we can investigate the current unevenness of economic globalization amongst European states. We compare three of these states that represent different degrees of potential 
peripheralization: Spain showing the stronger symptoms, Germany with least symptoms, and Britain somewhere in between. Our study is based upon an original analysis of advanced producer services that combines comparisons between countries and relations between cities.

In this paper we take a Jacobs' $(1969,1984,2000)$ view of economic development that treats states as economic jurisdictions but not actual functioning economies; cities (and city-regions) are the critical scale of economic process that expands and develops economies. Thus states are "grab bags of very different economies, rich regions and poor ones within the same nation" whereas "cities are unique in their abilities to shape and reshape the economies of other settlements, including those far away from them geographically" (Jacobs, 1984, p. 32). It follows that if Europe is to address its potential peripheralization it will have to do so through economic expansion of its cities; Europe's cities need to become dynamic again to match the cities of the more successful world regions. Our comparison of countries, therefore, is between the leading cities of Spain, Britain and Germany.

By focusing on cities we introduce relational thinking into the analysis. The vibrancy of dynamic cities derives from two distinct but related urban processes. Each generates an externality, a benefit beyond the market, a positive bonus for locating economic activity in the city. First there are dense patterns of intra-city relations that create agglomeration effects and cluster advantages. Second there are strong flows of inter-city relations that create network effects and connectivity advantages. All successful cities combine these agglomeration externalities and network externalities to maximise the bonus of an urban location. There is a massive and sophisticated literature on agglomeration effects (e.g. Fujita \& Thisse, 2002), but network externality effects have been much less studied. We concentrate on the latter as part of the Globalization and World Cities (GaWC) research programme where the study of network externalities has been pioneered. Specifically we draw on results from the research report Global Urban Analysis (Taylor et al., 2011) that presents findings from analysis of the 2008 survey of leading advanced 
producer service firms by GaWC in association with the Chinese Academy of Social Sciences.

\section{Methodology}

Contemporary network externalities are a function of world city network formation. This process has been modelled as an interlocking network. Networks usually consist of two layers, the net level and the node level. Formal city government associations work in this way with the cities (members) as nodes, the city association represents the net level, and the formal relations between members within the association define the network. Such networks can be an important component of global governance but this is not how cities operate as key components of the global economy. In the latter, it is advanced producer service firms that are the network makers; they create the world city network through their everyday practices linking offices across the world. This defines a different type of network, an interlocking network that is unusual in having three layers. In the case of the world city network there is the net level of the global economy, the node level of cities, and an additional sub-nodal level of service firms. The latter are not just an additional level, they define the critical level: this is where the agents of network formation are found. In the global economy, it is firms who are the network makers not the cities themselves. Thus for studying the world city network it is service firms that are investigated in order to understand the city network as the outcome. In other words, it is through studying the locational strategies of firms that it is possible to measure and analyse the world city network.

Why focus on these service firms? In the 1970s two separate industries, computers and communications, merged their technologies to enable work to be coordinated worldwide based upon simultaneous connections. Early on Sassen (1994) spotted two contrasting economic geography effects: first, a dispersal of production to cheaper labour locales, and second, a contrary trend towards concentration of management and business service industries. The latter were required to organize the new worldwide production and were 
concentrated in cities. As Sassen (1991) originally argued, it is concentration of management alongside financial, professional and creative services that characterises contemporary "global cities". Of course, service firms have always clustered in cities to provide such services to their clients but under conditions of contemporary globalization those specialised services became worldwide with fundamental implications for work practices. Firms need a multiple office policy across many cities to provide a seamless service and protect global brand integrity by keeping all work in-house.

This is how it came to be that from the 1980s onwards there have been hundreds of large service firms with trans-national office networks, many of them global in scope. Each firm had its own locational strategy - which cities to have offices in, what size and functions those offices will be, and how the offices will be organised. It is the work done in these offices that "interlock" various cities in projects that require multiple office inputs. Thus the inter-city relations in these servicing practices are numerous electronic communications - information, instruction, advice, planning, interpretation, strategy, knowledge, etc., some tele-conferencing as required, and probably travel for face-to-face meetings at a minimum for the beginning and end of a given project. These are the working flows that combined across numerous financial, professional and creative projects in multiple firms to constitute the world city network (Taylor, 2001, 2004).

So we have to study service firms to describe and analyse the world city network but, unfortunately, there is no feasible way that data could be collected from firms on these working flows. As well as the obvious confidentiality issues with competing private firms, there is also a feasibility issue: the degree of research collaboration that would be needed from a large number of firms makes such a data collection exercise beyond reasonable social science research logistics. However, this is not a particularly rare situation in measurement practices: where direct measures cannot be obtained, there is the fall back position of carrying out indirect measurement. This requires access to more easily available data plus credible assumptions about how the firms operate. 
As mentioned previously, service firms offer a seamless service across their office networks. This means that the geographical distribution of their offices, and their scope and range, are important selling points in attracting new clients. Hence such information is commonly available on service firms' web sites. This has been the main source of data for measuring the world city network: for each firm, offices are assessed individually by asking what is the importance of this office in this city within the firm's overall office network? Answers to this question are termed the service value of a city to a firm. These values are coded and become the quantitative input into the study: the coding ranges from 0 (a firm having no office in a city) to 5 (a city housing the headquarters of a firm); standard or typical offices of a firm score 2, minor and major offices 1 and 3 , respectively, leaving 4 for scoring cities housing exceptionally important offices such as regional headquarters. The credible assumption that is made is that the more important an office the more working flows it will generate. Therefore two important offices will generate a much higher level of flow between their respective cities than two minor offices between their respective cities. These data and this assumption are combined to generate estimates of inter-office working flow levels between cities for each firm; they are not actual working flows, but potential working flows, indirect measures derived from the data and the model assumptions. Aggregating all potential working flows for all firms located in a city generates estimates of its working flow relations with other cities; when this is done for all cities it constitutes the world city network.

Network connectivity is the main measure of importance of a city in this model (Taylor, 2001). It is computed from the products of service values for the city with each other city for all firms. Thus assuming $m$ advanced producer service firms and $n$ cities we can define a service value for firm $j$ in city $i$ as $v_{i j}$. The basic relational unit of measurement is given by

$$
r_{a b, j}=v_{a j} \cdot v_{b j}
$$


which defines the relation between cities $a$ and $b$ in terms of firm $j$. This is an elemental interlock between two cities for one firm. The aggregate cities interlock between the cities is then given by

$$
r_{a b}=\sum r_{a b, j}
$$

For each city there are $n-1$ such interlocks and the network connectivity for a city is given by

$$
C_{a}=\sum r_{a i} \quad \text { where } a \neq i
$$

where $C_{a}$ is the network connectivity of city a. This relates city $a$ to all other cities within the network through its firms and measures the degree of integration of the city into the world city network.

The data collection to operationalize this model and provide the results reported below was carried out in 2008 (Taylor et al., 2011). Office networks were coded for 175 advanced producer firms chosen as leading firms in their respective sectors: the top 25 in accountancy, advertising, law and management consultancy, and the top 75 firms for financial services (banking, insurance and diversified finance). For accountancy and advertising, firm choice was based on global ranks by revenue in World Accounting Intelligence (www.worldaccountingintelligence.com) and Advertising Age (www.adage.com). Law firms are those ranked highest by chambersandpartners.com, and management consultancies are leading firms by "prestige" as identified by www.vault.com. The 75 financial firms are those ranked top in the Forbes Global 2000 list (www.forbes.com). Their offices were scrutinized across 525 cities worldwide. The end result is a 525 cities $x$ 175 firms matrix with each cell indicating the importance of a specific city in the office network of a specific firm, 91,875 service values in all.

From this large amount of customized data we compute network connectivities of cities as defined in equation (3) to show the degree of a city's integration into the world city network. The values computed from equation (3) 
are relatively large and therefore to make them easier to interpret we present them as proportions of the highest scoring city. In addition we disaggregate these network connectivities in two ways.

1. By sector. This allows us to see the connectivity of a city generated by firms in just one sector. Thus we produce financial connectivities from the 75 firms in this sector, and accountancy connectivities, advertising connectivities, law connectivities and management consultancy connectivities from the 25 firms in each of the sectors. These connectivities are also presented as proportions of the largest connectivity.

2. By geographical area. This allows us to explore the "hinterworlds" of cities (Taylor, 2004). Here we focus on six connectivities based upon links to Pacific Asian cities, to Northern American cities and to European cities at one scale, and to New York and London, to Beijing, Hong Kong and Shanghai, and to other cities in a city's home country (i.e. Spain, Britain or Germany). These connectivities are shown as standardized variables (mean $=0$ and standard deviation $=1$ ) to indicate where a city is relatively over-linked and relatively under-linked.

Results are shown and discussed for Europe as a whole first before focusing on our three chosen countries. For the latter we focus on just the top five cities in terms of network connectivity in each country.

\section{European Cities in the World City Network}

Although it can be argued that the European Union has provided the general economic framework for the region's cities to prosper, their role as economic units has been largely neglected in European policy circles (van den Berg et al., 2007). European spatial planning (Faludi, 2002) has only very recently begun to address questions of globalization, mainly as international 
competitiveness. Thus although the EU now stretches across most of Europe from the Atlantic to the Black Sea, it has had little direct effect on European cities except where its major institutions are located, Brussels as "capital of Europe" (Baeten, 2001; Elmhorn, 2001; de Groof, 2008), and to a much lesser extent, Luxembourg, Strasbourg and Frankfurt.

Figure 1: Global network connectivities of European cities

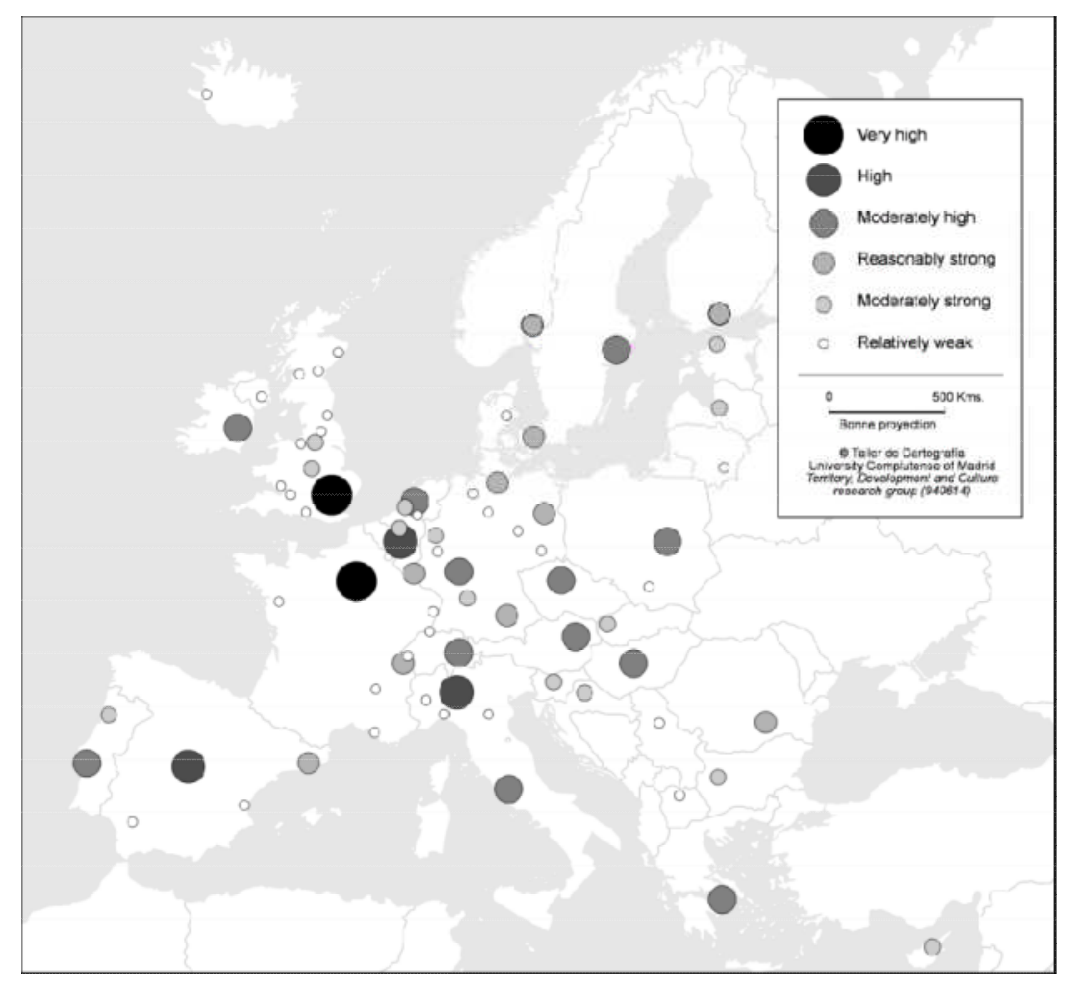

The evidence provided in this section consists of three sets of results. First, the cities with global network connectivities above 0.1 define the 74 cities that are depicted in Figure 1; using the actual connectivity proportions, gaps in these values are employed to identify six strata of cities. In addition, the top 25 ranks, designated the "leading" European cities in the world city network, are listed in the first city ranking in Table 1 . Second, the city connectivities are disaggregated by service sector producing five new rankings: for financial services the top 25 cities are shown as the second ranking in Table 1; for accountancy, advertising, legal services and management consultancy the top 10 cities are shown in Table 2. Third, city connectivities are disaggregated by geographical orientation in Table 3, showing over- or under-linkage to other 
European cities, and over- or under-linkage to the other two main globalization arenas, to Northern American cities and to Pacific Asian cities.

Figure 1 shows the many European cities integrated into the world city network to varying degrees - this world region has more such cities than any other world region (Taylor et al., 2011). This is partly because Europe remains a region of multiple states and globalizing service firms will want a presence in different states to tap into "national" markets. Very often this is accomplished by locating an office in a country's capital city, hence the map being dominated by capital cities: thus 14 of 17 cities recorded in the 3 "high" categories in Figure 1 are capitals, 13 out of 24 in the 2 "strong" categories, but only 4 out of 32 in the "weak" category. This domination of capital cities among the more connected cities is specifically shown in the first ranking list of Table 1 showing global network connectivities for leading European cities. With its score of 1 , this shows London to be the most connected city in the world. With Paris, the two leading European cities are indisputably "global cities" as famously described by Sassen (1991). For the rest of the table we divide the cities into groups at a much finer level than the map strata. Below Paris, Milan, Madrid and Brussels form a distinctive group with global network connectivities around two-thirds of the maximum. Brussels is not a surprise but the two southern European cities are less predictable at this level. The next group contains Warsaw, Zurich, Amsterdam, Dublin and Rome. These cities represent, in order, the post-communist rise of an Eastern European capital city, two important traditional financial centres, one of the major success stories of globalization, and the capital city of one of Europe's largest countries. The following group continues with a mix of capital cities of medium-sized countries (Lisbon, Stockholm, Vienna and Athens), including two - Prague and Budapest - from the former communist east, plus Frankfurt. The latter, another traditional financial centre, is interesting as it is Germany's first ranked city in terms of global network connectivity. Germany has by far the largest economy in Europe but has no city in the top 10 in Table 1. This reflects the country's very "horizontal" urban system, relating to its federal political structure and to the fact that its capital city, Berlin, was a divided city during the Cold War and has yet to fully recover economically (Cochrane and 
Jonas 1999; Krätke 2001). Berlin appears in the next stratum along with (i) other political capitals of much smaller countries (Oslo, Helsinki, Copenhagen) including another from the east (Bucharest), and (ii) another German city (Hamburg) and (iii) another traditional financial centre (Geneva).

Table 1. Top 25 European cities for global network connectivity (GNC) and financial network connectivity (FNC)

\begin{tabular}{|c|c|c|c|c|}
\hline Rank & City & GNC & City & FNC \\
\hline 1 & London & 1 & London & 1 \\
\hline 2 & Paris & 0.78 & Paris & 0.79 \\
\hline 3 & Milan & 0.69 & Madrid & 0.7 \\
\hline 4 & Madrid & 0.65 & Milan & 0.7 \\
\hline 5 & Brussels & 0.63 & Frankfurt & 0.61 \\
\hline 6 & Warsaw & 0.56 & Zurich & 0.6 \\
\hline 7 & Zurich & 0.55 & Brussels & 0.57 \\
\hline 8 & Amsterdam & 0.55 & Amsterdam & 0.56 \\
\hline 9 & Dublin & 0.54 & Dublin & 0.56 \\
\hline 10 & Rome & 0.53 & Warsaw & 0.5 \\
\hline 11 & Lisbon & 0.52 & Stockholm & 0.44 \\
\hline 12 & Frankfurt & 0.5 & Geneva & 0.43 \\
\hline 13 & Stockholm & 0.49 & Luxembourg & 0.41 \\
\hline 14 & Prague & 0.49 & Prague & 0.4 \\
\hline 15 & Vienna & 0.48 & Athens & 0.39 \\
\hline 16 & Budapest & 0.48 & Lisbon & 0.39 \\
\hline 17 & Athens & 0.48 & Rome & 0.35 \\
\hline 18 & Barcelona & 0.42 & Budapest & 0.33 \\
\hline 19 & Bucharest & 0.4 & Vienna & 0.32 \\
\hline 20 & Oslo & 0.4 & Munich & 0.29 \\
\hline 21 & Berlin & 0.39 & Berlin & 0.23 \\
\hline 22 & Helsinki & 0.39 & Bucharest & 0.22 \\
\hline 23 & Geneva & 0.38 & Barcelona & 0.22 \\
\hline 24 & Copenhagen & 0.37 & Düsseldorf & 0.2 \\
\hline 25 & Hamburg & 0.37 & Bratislava & 0.2 \\
\hline
\end{tabular}

The other ranking in Table 1 shows the connectivity produced just by financial service firms. Notice the distribution of connectivity levels for these services is different from the general results. Although levels of connectivity are similar for the leading cities, city connectivities for finance fall away rapidly after the ninth rank indicating that financial service firms alone generate a much more 
concentrated pattern of connectivity in Europe. Realistically, therefore, there were just nine international financial centres in 2008 and since then, the ninth, Dublin, has reduced to below this standard. Looking at the specifics, the top two remain the same, London and Paris, but Madrid now ranks above Milan. The biggest riser is Frankfurt that, with Zurich, is now more connected than Brussels. Also Luxembourg, Munich and Düsseldorf join the top 25.

Table 2. Leading cities for network connectivity in accountancy, advertising, law and management consultancy

\begin{tabular}{|c|c|c|c|c|c|}
\hline Rank & City & Accountancy & Rank & City & Advertising \\
\hline 1 & London & 1 & 1 & London & 0.75 \\
\hline 2 & Milan & 0.67 & 2 & Paris & 0.75 \\
\hline 3 & Paris & 0.66 & 3 & Warsaw & 0.63 \\
\hline 4 & Brussels & 0.59 & 4 & Brussels & 0.62 \\
\hline 5 & Lisbon & 0.57 & 5 & Athens & 0.6 \\
\hline 6 & Rome & 0.57 & 6 & Stockholm & 0.6 \\
\hline 7 & Berlin & 0.56 & 7 & Madrid & 0.6 \\
\hline 8 & Madrid & 0.56 & 8 & Milan & 0.6 \\
\hline 9 & Oslo & 0.55 & 9 & Budapest & 0.57 \\
\hline 10 & Barcelona & 0.55 & 10 & Vienna & 0.56 \\
\hline
\end{tabular}

\begin{tabular}{|c|c|c|c|c|c|}
\hline Rank & City & Law & Rank & City & $\begin{array}{c}\text { Management } \\
\text { consultancy }\end{array}$ \\
\hline 1 & London & 1 & 1 & London & 0.67 \\
\hline 2 & Paris & 0.7 & 2 & Paris & 0.65 \\
\hline 3 & Frankfurt & 0.59 & 3 & Zurich & 0.55 \\
\hline 4 & Brussels & 0.54 & 4 & Madrid & 0.55 \\
\hline 5 & Amsterdam & 0.4 & 5 & Rome & 0.48 \\
\hline 6 & Munich & 0.4 & 6 & Amsterdam & 0.47 \\
\hline 7 & Milan & 0.39 & 7 & Dublin & 0.47 \\
\hline 8 & Madrid & 0.37 & 8 & Frankfurt & 0.47 \\
\hline 9 & Warsaw & 0.34 & 9 & Milan & 0.46 \\
\hline 10 & Düsseldorf & 0.32 & 10 & Stockholm & 0.44 \\
\hline
\end{tabular}

Table 2 shows top ten city connectivity rankings for the other advanced producer services. They can be divided into two sets: in accountancy and legal services, London is the global leader and therefore completely dominates other European cities; advertising and management consultancy are archetypal American contributions to the professional services and 
therefore New York dominates globally. In these cases Paris joins with London as the top European stratum of cities.

The two London dominated services are, however, very different in all other respects. Accountancy is the most ubiquitous of the services treated in this analysis and legal services are the most concentrated. This creates contrasting city service structures: accountancy scores are much "flatter" than those for law. For instance, cities ranked tenth have connectivities of 0.55 and 0.32 respectively. The specifics are best represented by German cities: the capital Berlin appears in the accountancy list reflecting a general market attraction; Frankfurt, Munich and Düsseldorf are in the law list reflecting a finance market attraction.

For the two New York dominated services, Paris joins London in the top stratum due to the relatively low level of London's connectivities for these services: London drops to Paris's general level rather than vice versa. Below these two cities the scores for advertising have a flatter distribution that is dominated by capital cities, or more generally by cities with TV stations that are the main market for this service. Scores for management consultancy show a more concentrated pattern of connectivities and tend to mirror the financial services connectivities with its mixture of financial centres and capital cities.

Table 3 shows the geographical orientation results for the top 25 cities (as indicated by overall network connectivity in Table 1). Not surprisingly for the local region, in the first list for European concentration of connections all cities bar one have positive scores, which means that they are relatively more connected to other European cities than to cities outside Europe. The odd one out is London with a very small negative score and this reflects the fact that the more important cities in Table 1 are less focused on connections to their European neighbours. Paris, Milan and Madrid are ranked in the bottom ten but Brussels is predictably ranked higher as the "capital of Europe". It is not unusual for major cities of a world region to be more orientated away from their region; this is what makes them world or global cities, and London has 
been so categorised as "un-European" previously (Taylor and Hoyler, 2000; Taylor and Derudder, 2004). Conversely less connected cities from Table 1 have relatively high connections to other European cities: Hamburg, Copenhagen and Oslo fit into this category. Geneva is the big exception with relatively low European links (ranked 24th) and low general connectivity (23rd in Table 1); which is the converse of Warsaw with relatively high European links (ranked 3rd) and high general connectivity (ranked 6th in Table 1). Therefore the "localism" of European city hinterlands is only loosely related to general connectivity; specific city functions (Geneva in international finance) and even location (Athens bordering other regions) is sometimes important.

Orientations to Northern American cities are shown in the second list in Table 3 and indicate that the vast majority of leading European cities are relatively under-linked to Northern America. The pattern is fairly straightforward with the cities ranking high on financial connectivity in Table 1 also being relatively over-linked to Northern America; the respective top tens in these lists largely overlap. Those relatively under-linked to Northern America are capital cities of smaller countries, the bottom nine on the list match this description. The orientations to Pacific Asian cities shown in the third list in Table 3 have a similar financial bias to those on the previous list but with higher positive scores. This reflects a much more balanced pattern between under- and overlinkage. Zurich is the exception among international financial centres suggesting its long established embedding in old financial markets is not being transferred to new financial centres in Pacific Asia. At the under-linked end of the scale capital cities no longer feature as prominently as for Northern American connections. Previous research has shown that Pacific Asian cities are especially strong in financial services (Taylor, 2004) and this new finding shows how this global pattern is strongly reflected in the hinterworlds of leading European cities. 
Table 3. Relative links to major world regions: top 25 cities

\begin{tabular}{|c|c|c|c|c|c|c|}
\hline Rank & City & Europe & City & $\begin{array}{l}\text { Northern } \\
\text { America } \\
\end{array}$ & City & $\begin{array}{c}\text { Pacific } \\
\text { Asia }\end{array}$ \\
\hline 1 & Hamburg & 3.52 & Amsterdam & 0.53 & Frankfurt & 2.46 \\
\hline 2 & Stockholm & 2.86 & London & 0.1 & London & 1.86 \\
\hline 3 & Warsaw & 2.67 & Milan & 0.07 & Paris & 1.41 \\
\hline 4 & Budapest & 2.54 & Zurich & 0 & Amsterdam & 1.15 \\
\hline 5 & Copenhagen & 2.45 & Madrid & -0.02 & Milan & 0.76 \\
\hline 6 & Bucharest & 2.41 & Paris & -0.06 & Madrid & 0.6 \\
\hline 7 & Oslo & 2.41 & Dublin & -0.09 & Prague & 0.6 \\
\hline 8 & Lisbon & 2.36 & Frankfurt & -0.23 & Geneva & 0.34 \\
\hline 9 & Vienna & 2.36 & Rome & -0.3 & Brussels & 0.32 \\
\hline 10 & Zurich & 2.27 & Stockholm & -0.57 & Dublin & 0.07 \\
\hline 11 & Brussels & 2.2 & Brussels & -0.87 & Warsaw & 0.02 \\
\hline 12 & Rome & 2.14 & Berlin & -1.05 & Budapest & -0.07 \\
\hline 13 & Barcelona & 2.14 & Oslo & -1.12 & Zurich & -0.2 \\
\hline 14 & Berlin & 2.09 & Geneva & -1.14 & Vienna & -0.24 \\
\hline 15 & Prague & 1.84 & Hamburg & -1.16 & Lisbon & -0.57 \\
\hline 16 & Frankfurt & 1.75 & Barcelona & -1.2 & Rome & -0.6 \\
\hline 17 & Madrid & 1.62 & Warsaw & -1.46 & Athens & -0.67 \\
\hline 18 & Helsinki & 1.33 & Lisbon & -1.61 & Stockholm & -0.76 \\
\hline 19 & Dublin & 1.27 & Prague & -1.63 & Bucharest & -1.12 \\
\hline 20 & Paris & 1.17 & Athens & -1.71 & Berlin & -1.14 \\
\hline 21 & Athens & 1.02 & Vienna & -1.85 & Oslo & -1.23 \\
\hline 22 & Amsterdam & 0.93 & Helsinki & -2.24 & Barcelona & -1.24 \\
\hline 23 & Milan & 0.8 & Budapest & -2.53 & Helsinki & -1.3 \\
\hline 24 & Geneva & 0.14 & Copenhagen & -2.58 & Copenhagen & -1.42 \\
\hline 25 & London & -0.01 & Bucharest & -3.51 & Hamburg & -1.48 \\
\hline
\end{tabular}

In conclusion, Europe, as the cradle of modernity and for more contemporary reasons, has many cities well integrated into the world city network. However, the degree of integration varies greatly with London, then Paris, the most integrated cities, especially in the core world regions of economic globalization. Patterns vary between different service sectors - Frankfurt and Zurich rise for financial services, Milan and Lisbon for accountancy, Warsaw and Athens for advertising, Frankfurt and Amsterdam for law, and Zurich and Rome for management consultancy. When it comes to geographical orientations, connectivities to Northern American and Pacific Asian cities largely reflect the pattern of financial centres in Europe: it is this 
finance/Pacific Asia link in city connectivities that may well be the key discriminating factor in the future economic successes of European cities.

\section{British Cities in the World City Network}

The UK space economy has long been notorious for its primate pattern of cities centred on London and the South East. For much of the twentieth century, UK governments pursued regional policies specifically to counter "the drift to the South" resulting from the decline of the industrial cities and towns of northern Britain from their nineteenth century economic prime. But such policies proved to have limited impact on the economic forces creating London's primacy. With the rise of neoliberal globalization from the late 1970s, the prospects for the cities collectively known as "not-London" seemed to have been further reduced: the demise of regional policy was followed by government policy that precipitated the City of London's "Big Bang". This opened up the City to foreign banks and other financial services to ensure London would become a key locale for on-going economic globalization. In 1991 Saskia Sassen announced that London, with New York and Tokyo, was an archetypal "Global City".

With this global position added to London's national dominance, it seemed that London's UK primacy in the new world of globalization would be greater than ever. And this was confirmed by the first measurement of global network connectivities in 2000 (Taylor et al., 2002; Taylor, 2004): London was ranked first globally and with no other UK city in the top 100 (Beaverstock et al., 2001). Other studies have highlighted the economic underperformance of UK provincial cities compared to their European counterparts (e.g. Parkinson et al., 2004, 2006). However, at the beginning of the twenty first century there appeared to be a revival of provincial UK cities. New measures of global network connectivity in 2004 showed that UK cities had experienced some of the most rapid increases in global network connectivities in the world: Edinburgh, Bristol, Cardiff and Leeds being particular noteworthy in this respect (Taylor and Aranya, 2006). Further work has indicated that the UK space economy, while not becoming fully "balanced", has been developing 
inter-city networks to complement the continuing London-headed urban hierarchy. In other words, since 2000, major global service providers have found it worth their while to make use of UK provincial cities as well as London (Taylor et al., 2009, 2010). This is the context in which to consider UK cities in the 2008 world city network analysis.

Table 4 shows global network connectivities for the top 5 UK cities to illustrate how well the leading British cities are integrated into the world city network. The outstanding result is no surprise: the continuing dominance of London. While other UK cities are still not major players in the world city network, there are now some moderately important world cities that can be identified with about one fifth of London's connectivity. Manchester, Glasgow and Birmingham have been in competition to be the UK's "second city" for more than a century and they continue to be leading cities in globalization but are now joined by Edinburgh, Europe's newest financial centre. Manchester and Birmingham are the centres of the two major economic regions outside the South East, the North West and West Midlands respectively, and are reinventing themselves as new European and world cities. Edinburgh is the fast riser based upon being the capital city of Scotland, the UK's main political devolution (with its new service needs), as well as being home to successful banks (before the credit crisis when these data were collected; see Derudder et al., 2011). Glasgow has traditionally been the economic centre for Scotland but may now be being overtaken by its neighbour Edinburgh; however it is still of some importance within contemporary globalization. The overall message of this table is not that any UK city is seriously rivalling London but that leading British cities across the country are integrated into the world city network to a moderate degree.

Nevertheless, the second list in Table 4 indicates that we should not take this argument for worldwide integration of UK provincial cities too far. This shows measures of "localism" at the national level, the degree to which a city's connectivity is dominated by links to other cities within the country. The list emphasizes the separation of London from the rest; the city is strongly underlinked in its relations to other British cities. With a large negative score, 
London is shown to be very "un-local": the vast majority of its connections are beyond the UK. The other four cities have positive scores indicating the importance of domestic links relative to foreign connections. However, the results do show that it is Manchester that is the least local, confirming its position as the British provincial city most integrated into the world city network.

Table 4. Connectivity of leading UK cities and their "localism"

\begin{tabular}{|c|l|c|c|}
\hline Rank & \multicolumn{1}{|c|}{ City } & GNC & With other UK cities \\
\hline 1 & London & 1 & -1.31 \\
\hline 2 & Manchester & 0.22 & 2.47 \\
\hline 3 & Edinburgh & 0.21 & 3.28 \\
\hline 4 & Birmingham & 0.21 & 3.32 \\
\hline 5 & Glasgow & 0.19 & 3.04 \\
\hline
\end{tabular}

Table 5. Globalization orientations of leading UK cities

\begin{tabular}{|l|c|c|}
\hline \multicolumn{1}{|c|}{ City } & NYLON globalization & China globalization \\
\hline London & - & 0.95 \\
\hline Manchester & 0.01 & -0.08 \\
\hline Edinburgh & 0.06 & -0.06 \\
\hline Birmingham & -0.17 & -0.22 \\
\hline Glasgow & -0.13 & -0.05 \\
\hline
\end{tabular}

The first list in Table 5 measures the "traditional globalism" of UK cities by showing their combined connectivity to London and New York, NYLON, as the "main street dyad" of contemporary globalization (therefore there is no score for London in this list). The provincial cities here divide into two pairs with positive scores for Manchester and Edinburgh and negative scores for Birmingham and Glasgow. The second list in Table 5 shows city connections to what may be an emerging new globalism based upon Beijing, Shanghai and Hong Kong. Once again London stands out with its large positive connection to this Chinese tri-city centre; the other cities are all relatively under-linked for this China connection. There are no signs that leading provincial British cities are getting into place to benefit from the China globalization that may dominate the twenty first century (Taylor, 2013). 
In conclusion, the analysis of 2008 GaWC data has generally confirmed recent writings on UK cities in globalization: London continues to completely dominate the connections between the UK and the rest of the world economy as measured by business service links. Leading provincial cities are becoming moderately important service nodes in their own right but the primacy of London is as strong, or perhaps even stronger, with the coming of economic globalization.

\section{German Cities in the World City Network}

In contrast to the British case of extreme primacy in global network connectivity, German cities show a much more balanced integration into the locational networks of leading advanced producer service firms (Hoyler 2011). This is in part due to the long history of territorial fragmentation and political decentralization of state power, which has led to the emergence of a polycentric urban system with complementary functional and sectoral specialization (Blotevogel, 2000). Metropolitan functions are distributed across a number of important cities and city-regions (Krätke, 2004; Blotevogel and Schulze, 2009), in particular those designated "European Metropolitan Regions" in recent spatial policy agendas (BBR, 2005).

Of the 14 German cities with over 500,000 inhabitants, there are five which show a global network connectivity of over $30 \%$ of that of the worldwide leading city, London (Table 6). The highest ranked city in Germany is Frankfurt am Main, reflecting its role as a major international financial centre that attracts not only financial service firms but has become a national gateway for many other knowledge-intensive business services (Hoyler et al., 2008). While Frankfurt clearly stands out, Germany's three largest cities, Berlin, Hamburg and Munich, follow with only minor differences in their global network connectivity scores. For the capital Berlin this reflects an increased importance after the end of the Cold War, which had limited its potential for economic growth (Korcelli-Olejniczak, 2012). Hamburg, the major port and economic centre in northern Germany, and Munich, the southern German manufacturing and high-technology hub (Lüthi et al., 2010) are followed 
closely by Düsseldorf, the principal advanced producer service location for the Rhine-Ruhr region, and by Stuttgart (ranked sixth with 0.27 ), the centre for corporate servicing of South-West Germany (Strambach, 2002). However, the remaining eight cities with over 500,000 inhabitants all achieve global network connectivity scores of over 0.05 , with five cities showing over ten per cent of London's connectivity. Cologne leads this group of second-tier service centres, ahead of Leipzig, Dresden, Bremen and Hannover (see Hoyler, 2011).

The "localism" measure in Table 6 underlines the specific role of Frankfurt as Germany's "most international" city: as the only city with a (slight) negative score, its connectivity in advanced producer servicing is balanced between national and transnational links. This reflects its particular strengths in corporate law (rank 3 in Europe; Table 2), finance (rank 5; Table 1) and management consultancy (rank 8; Table 2). Other German cities make it into the European Top Ten only once: Berlin in accountancy (rank 7, Table 2), and Munich and Düsseldorf in corporate law (ranks 6 and 10 respectively; Table 2). The positive scores of these cities on the "localism" measure indicate the relative importance of domestic over foreign connections, with Berlin and Munich less domestically oriented than Hamburg and Düsseldorf (Table 6). Compared to British provincial cities (Table 4) however, German cities are significantly more "un-local", reflecting the export-orientation of the German economy and the associated need for cross-border service provision.

Table 7 focuses on selected geographical patterns of these non-domestic linkages to the traditional centres of global capital, New York and London (NYLON), and to the new emerging focus of contemporary globalization in China (Beijing - Hong Kong - Shanghai). The top five German cities show a remarkable degree of similarity in their aggregate advanced producer service connections to these two major poles of globalization: With the exception of Berlin, all cities are relatively over-linked to NYLON and to the Chinese city triad. Frankfurt once again is ahead of other German cities in terms of the intensity of these connections, followed by Munich, Düsseldorf and Hamburg. The relative strength of these linkages compared to provincial UK (Table 5) 
and Spanish (Table 9) cities may well signify a more favourable positioning of German cities in a changing global economic order.

Table 6. Connectivity of leading German cities and their "localism"

\begin{tabular}{|c|l|c|c|}
\hline Rank & \multicolumn{1}{|c|}{ City } & GNC & With other German cities \\
\hline 1 & Frankfurt & 0.5 & -0.05 \\
\hline 2 & Berlin & 0.39 & 0.65 \\
\hline 3 & Hamburg & 0.37 & 0.89 \\
\hline 4 & Munich & 0.35 & 0.75 \\
\hline 5 & Düsseldorf & 0.32 & 0.84 \\
\hline
\end{tabular}

Table 7. Globalization orientations of leading German cities

\begin{tabular}{|l|c|c|}
\hline \multicolumn{1}{|c|}{ City } & NYLON globalization & China globalization \\
\hline Frankfurt & 1.29 & 1.09 \\
\hline Berlin & -0.12 & -0.23 \\
\hline Hamburg & 0.12 & 0.01 \\
\hline Munich & 0.9 & 0.77 \\
\hline Düsseldorf & 0.48 & 0.4 \\
\hline
\end{tabular}

In conclusion, although Frankfurt emerges as the leading German city in terms of global network connectivity, the analysis of the 2008 GaWC data has also confirmed the relative strength of other German cities in their integration into worldwide advanced producer services networks. Berlin, Hamburg and Munich share similar overall levels of integration but are marked by sectorspecific differences in the strength of their linkages. Düsseldorf and Stuttgart complete the leading group of six cities that act as prime strategic nodes in the organizational networks of major advanced producer service firms who operate parts of their business from/in Germany. The analysis confirms the enduring polycentric nature of the German urban system, even when viewed through the lens of globally operating advanced producer service firms.

\section{Spanish Cities in the World City Network}

Five big urban areas lead the Spanish city network; the two metropolises of international renown (Madrid and Barcelona) and three regional metropolises (Valencia, Seville and Bilbao). According to Urban Audit data, in 2009 Madrid 
had 6,271,638 inhabitants and Barcelona 4,440,629. This demographic feature has been interpreted as the doubled-headed character of the Spanish urban network, halfway between vertical and horizontal national city structures. Other urban areas of the country appear close to this leading group, of which only Bilbao falls just below the threshold of one million inhabitants.

The recent evolution of Spanish cities has been shaped by an intense economic-territorial restructuring process associated with globalization and technological change. Two key factors help explain the strengthening of big cities that has occurred over the last decades. First, the influence of the decentralized nature of the Spanish state, favouring the emergence of regional urban networks, more integrated locally and headed by regional centres that maintain intense relations with each other and with the two national metropolises. Second, the reinforcing view of Spanish cities as relevant global actors competing with other cities nationally and in Europe.

Although the last perspective has dominated recent urban policies and strategies in Spain, the empirical knowledge has not advanced in parallel. Certainly, Spanish cities have only marginally been considered within international research on world cities, as shown by a review of the main published works during the 1990s (Taylor, 2004). However, some general findings can be summarised from previous research conducted on global office networks of advanced business services. Madrid and Barcelona act as "classic gateway cities" in contemporary globalization, connecting the national to the world economy (Taylor, 2004). However, Madrid occupies a higher position in the world urban hierarchy and is considered a major global service centre for the key sectors of advertising, accountancy, banking/insurance and legal services (Beaverstock et al., 2000). Moreover, in a general context of an increasing concentration of advanced services in leading world cities, the net connectivity gains of Madrid in the early 2000s are confirmed against the losses of neighbouring cities, such as Lisbon or Barcelona (Taylor et al., 2003). The international roles also vary along the world city network configurations; Madrid has been classified within a "global route arena" 
(intercontinental linkages), highlighting its financial services connections with important Latin American cities (reinforcing historical linkages). Barcelona, partially in the same cities group, presents some characteristics similar to other European financial centres connected with the great banking cities of Asia Pacific. Other Spanish cities belong to "European urban arenas" of national scope that, unlike the main economies of the continent (Germany, UK and France), do not constitute a specific cluster (Taylor et al., 2002).

According to the 2008 GaWC data, only five of the bigger Spanish cities reach a global network connectivity above 0.05 (proportionally to the maximum connectivity of London; Table 8). Their position fits the population size distribution, Madrid leading the connectivity of Spanish cities with nearly two thirds of the highest global network connectivity. The leadership of Madrid as the centre of the Spanish economy is based upon its status as political capital and also reflects an increasing specialization in advanced tertiary activities (OECD, 2007). Other relevant factors include the strong performance of its real estate market and the success of cluster promoting policies, including the services of international fairs (Cuadrado-Roura and Rubalcaba-Bermejo, 1998; Sánchez Moral et al., 2008).

Barcelona, second in the ranking, is the other half of the traditional dual primacy pattern of the Spanish urban system, always striving to escape from the shadow of Madrid as the dominant local world city. Despite competition with Madrid to attract big companies, economic institutions or international organisations, which seems to favour the Spanish capital as the place to locate, the economic performance of Barcelona in globalization is clearly influenced by its history as capital of the main manufacturing region of the country. Nowadays, Barcelona has developed a successful urban development model that, without relinquishing the importance of high-tech manufacturing, reinforces the attractiveness for national and international advanced business services firms and especially for creative industries, being internationally recognized as a cultural-creative European hub (Boix, 2011). 
Table 8. Connectivity of leading Spanish cities and their "localism"

\begin{tabular}{|c|l|c|c|}
\hline Rank & \multicolumn{1}{|c|}{ City } & GNC & With other Iberian cities \\
\hline 1 & Madrid & 0.65 & -0.63 \\
\hline 2 & Barcelona & 0.42 & -0.01 \\
\hline 3 & Valencia & 0.12 & 0.53 \\
\hline 4 & Seville & 0.11 & 0.61 \\
\hline 5 & Bilbao & 0.09 & 0.67 \\
\hline
\end{tabular}

Table 9. Globalization orientations of leading Spanish cities

\begin{tabular}{|c|c|c|}
\hline City & NYLON globalization & China globalization \\
\hline Madrid & 0.67 & 0.71 \\
\hline Barcelona & 0.15 & 0.04 \\
\hline Valencia & -0.55 & -0.30 \\
\hline Seville & -0.42 & -0.35 \\
\hline Bilbao & -0.66 & -0.60 \\
\hline
\end{tabular}

The best way to approach the rest of the Spanish cities is through the alternative analysis of "localism". Thus, the relative concentration of domestic connections within the country rises significantly in Bilbao, Seville and Valencia, second order metropolises displaying a certain international projection but mainly dealing with the articulation at the regional level of the territory and the economy. On the other hand, the "localism" data also provide new evidence about divergence at the top of the urban network. Madrid is the only city that could be considered "un-local", while in Barcelona, only slightly negative on this score, the weight of the domestic connections continues to be quite important.

The relative concentration of connections with New York and London, or "NYLON globalization", confirms the increase in distance between Madrid and the rest of the Spanish cities, including Barcelona (Table 9). Even more intense are the differences found in the connections with the new economic centre of gravity represented by the Chinese cities of Beijing, Hong Kong and Shanghai. The values of "China globalization" highlight an even greater preponderance of Madrid in articulating the flows in this area, while Barcelona is clearly penalised by this new criterion, being only very weakly positive on this measure. Other big Spanish cities show negative values. 
In summary, despite the intermediate position of the urban structure of Spain, characterized by a doubled-headed city network and recent regional decentralization, there are strong differences in the integration of Spanish cities into the world city network. Madrid, a second order world city, acts as a "gateway city" connecting the national and the global economy. Barcelona shares this function to some extent but displays a lower degree of specialization in advanced producer services and fewer external connections of these activities. Although for regional metropolises local connections are even more important, due to their territorial articulation function, they also strive to achieve some international projection by means of attracting advanced business services, which are assumed to be strategic for their future urban development.

\section{Conclusion: How Resilient Is Europe and Its Cities?}

This snapshot of the network externalities of European cities in three countries in 2008 suggests a relatively healthy resilience in the face of economic crises. Europe as a whole has numerous cities comparatively well connected within the world city network due to its multiple states, and in the three states we focussed on, despite major differences in national urban structures, all the leading cities have reasonable overall connections and the major cities have strong connections to the competing centres of economic globalization (NYLON and China). But as we noted in the introduction we cannot yet know how the economic crisis will pan out as a global restructuring of the world-economy. We do have some new evidence from a later survey conducted in 2010, which we are just beginning to digest. For Europe this shows little change except for some specific, and expected, examples. Athens is the big loser with its world city network ranking dropping from 37th to 60th indicating a strong symptom of peripheralization. Also Edinburgh is the biggest loser within our three countries: Europe's "newest banking centre" was home to vulnerable banks resulting in a world city network ranking drop from 117 th to 128 th. Otherwise European cities still appear relatively resilient although Madrid dropping to 17th from 11th in world city network ranking may be cause for concern. 


\section{Acknowledgements}

This text is part of Spanish R\&D\&I projects CSO2009-10888 and CSO20112652

\section{References}

Baeten, G., 2001. The Europeanization of Brussels and the urbanization of "Europe". European Urban and Regional Studies 8, 117-130.

BBR (Bundesamt für Bauwesen und Raumordnung), 2005. Raumordnungsbericht 2005. BBR, Bonn.

Beaverstock, J. V., Hoyler, M., Pain, K., Taylor, P. J. 2001. Comparing London and Frankfurt as World Cities: A Relational Study of Contemporary Urban Change. Anglo-German Foundation, London.

Beaverstock J. V., Smith, R. G., Taylor, P. J., Walker, D. R. F., Lorimer, H. 2000. Globalization and world cities: some measurement methodologies. Applied Geography 20, 43-63.

Blotevogel, H. H., 2000. Gibt es in Deutschland Metropolen? Die Entwicklung des deutschen Städtesystems und das Raumordnungskonzept der “Europäischen Metropolregionen”. In: Matejovski, D. (Ed.), Metropolen: Laboratorien der Moderne. Campus, Frankfurt am Main, pp. 179-208.

Blotevogel, H. H., Schulze, K., 2009. Zum Problem der Quantifizierung der Metropolfunktionen deutscher Metropolregionen. In: Knieling, J. (Ed.), Metropolregionen: Innovation, Wettbewerb und Handlungsfähigkeit. Akademie für Raumforschung und Landesplanung (ARL), Hannover, pp. 30-58.

Boix, R., 2011. Facing globalization and increased trade: Catalonia's evolution from industrial region to knowledge and creative economy. Regional Science Policy \& Practice. doi: 10.1111/j.1757-7802.2011.01057.x 
Cochrane, A., Jonas, A., 2001. Reimagining Berlin: world city, national capital or ordinary place? European Urban and Regional Studies 6, 145-164.

Cuadrado-Roura, J. R., Rubalcaba-Bermejo, L., 1998. Specialization and competition amongst European cities: a new approach through fair and exhibition activities. Regional Studies 32, 133-147.

de Groof, R. (Ed.), 2008. Brussels and Europe. BRIO, Brussels.

Derudder, B., Hoyler, M., Taylor, P. J., 2011. Goodbye Reykjavik: international banking centres and the global financial crisis. Area 43, 173-182.

Elmhorn, C. 2001. Brussels: A Reflexive World City. Almqvist \& Wiksell International, Stockholm.

Faludi, A. (Ed.), 2002. European Spatial Planning. Lincoln Institute of Land Policy, Cambridge, MA.

Fujita, M., Thisse, J.-F., 2002. Economics of Agglomeration: Cities, Industrial Location and Regional Growth. Cambridge University Press, Cambridge.

Hoyler, M., 2011. External relations of German cities through intra-firm networks - a global perspective. Raumforschung und Raumordnung 69, 147159.

Hoyler, M., Freytag, T., Mager, C., 2008. Connecting Rhine-Main: the production of multi-scalar polycentricities through knowledge-intensive business services. Regional Studies 42, 1095-1111.

Jacobs, J., 1969. The Economy of Cities. Random House, New York.

Jacobs, J., 1984. Cities and the Wealth of Nations. Random House, New York. 
Jacobs, J., 2000. The Nature of Economies. Modern Library, New York.

Korcelli-Olejniczak, E., 2012. Marked by dynamics: Berlin and Warsaw in the process of functional change. In: Derudder, B., Hoyler, M., Taylor, P. J., Witlox, F. (Eds.), International Handbook of Globalization and World Cities. Edward Elgar, Cheltenham, pp. 517-529.

Krätke, S., 2001. Berlin: towards a global city? Urban Studies 38, 1777-1799.

Krätke, S., 2004. Urbane Ökonomien in Deutschland: Clusterpotenziale und globale Vernetzungen. Zeitschrift für Wirtschaftsgeographie 48, 146-163.

Lüthi, S., Thierstein, A., Goebel, V., 2010. Intra-firm and extra-firm linkages in the knowledge economy: the case of the emerging mega-city region of Munich. Global Networks 10, 114-137.

OECD, 2007. OECD Territorial Reviews: Madrid, Spain. OECD, Paris.

Parkinson, M., Champion, T., Simmie, J., Turok, I., Crookston, M., Katz, B., Park, A., 2006. State of the English Cities. Office of the Deputy Prime Minister (ODPM), London.

Parkinson, M., Hutchins, M., Simmie, J., Clark, G., Herdonk. H., 2004. Competitive European Cities: Where Do the Core Cities Stand? Office of the Deputy Prime Minister (ODPM), London.

Sánchez-Moral, S., Calatrava, A., Melero, A., 2008. Las funciones comando de Madrid en la economía global: una aproximación a través del proceso de atracción de capital extranjero. EURE-Revista Latinoamericana de Estudios Urbano Regionales 34, 25-44.

Sassen, S., 1991. The Global City: New York, London, Tokyo. Princeton University Press, Princeton, NJ. 
Sassen, S., 1994. Cities in a World Economy. Pine Forge Press, Thousand Oaks.

Strambach, S., 2002. Change in the innovation process: new knowledge production and competitive cities - the case of Stuttgart. European Planning Studies 10, 215-231.

Taylor, P. J., 2001. Specification of the world city network. Geographical Analysis 33, 181-194.

Taylor, P. J., 2004. World City Network: A Global Urban Analysis. Routledge, London.

Taylor, P. J., 2013. Extraordinary Cities: Millennia of Moral Syndromes, World-Systems and City/State Relations. Edward Elgar, Cheltenham.

Taylor, P. J., Aranya, R., 2006. Connectivity and city revival', Town \& Country Planning, 75, 309-314.

Taylor, P. J., Catalano, G., Gane, N., 2003. A geography of global change: cities and services, 2000-2001. Urban Geography 24, 431-441.

Taylor, P. J., Catalano, G., Walker, D. R. F., 2002. Measurement of the world city network. Urban Studies 39, 2367-2376.

Taylor, P. J., Derudder, B., 2004. Porous Europe: European cities in global urban arenas. Tijdschrift voor Economische en Sociale Geografie 95, 527538.

Taylor, P. J., Evans, D. M., Hoyler, M., Derudder, B., Pain, K., 2009. The UK space economy as practised by advanced producer service firms: identifying two distinctive polycentric city-regional processes in contemporary Britain. International Journal of Urban and Regional Research 33, 700-718. 
Taylor, P. J., Hoyler, M., 2000. The spatial order of European cities under conditions of contemporary globalisation. Tijdschrift voor Economische en Sociale Geografie 91, 176-189.

Taylor, P. J., Hoyler, M., Evans, D. M., Harrison, J., 2010. Balancing London? A preliminary investigation of the 'Core Cities' and 'Northern Way' spatial policy initiatives using multi-city corporate and commercial law firms. European Planning Studies 18, 1285-1299.

Taylor, P. J., Ni, P., Derudder, B., Hoyler, M., Huang, J., Witlox, F. (Eds.), 2011. Global Urban Analysis: A Survey of Cities in Globalization. Earthscan, London.

van den Berg, L., Braun, E., van der Meer, J., Mingardo, M. 2007. The urban dimension in European policy: history, actors and programmes. In: van den Berg, L., Braun, E., van der Meer, J. (Eds.), National Responses to Urban Challenges in Europe. Ashgate, Aldershot, pp. 39-62. 